\title{
DETERMINATION OF ALUMINUM IN INFANT MILK POWDER SERVING IN PEDIATRICS ASSIUT UNIVERSITY HOSPITAL
}

\author{
NAGAH, M. SAAD* and YASSER, S. WAFY** \\ * Professor of Milk Hygiene, Faculty of Vet. Med. Assiut University \\ *** Fellow, Assiut University Hospitals
}

Email: yasser wafy 2014@yahoo.com

\section{ABSTRACT}

Received at: 2/9/2014

Accepted: 19/10/2014
A total of 30 random samples of infant milk powder serving in pediatrics Assiut university hospital were collected at the time form January to March 2014 for estimate aluminum concentration in them. All examined samples were found to be contaminated with aluminum and its concentration / ppm was ranged from 0.0619 to 0.9601 with an average $0.4027 \mathrm{ppm}$. The highest frequency distribution was 18 (60\%) lied within the range of 0.2 and $0.4 \mathrm{ppm}$. The resultes in our study was agree with the Egyptian organization for standardization and quality control (2012) that lied within the range of legal limit $(0-4 \mathrm{ppm})$. The healthy importance of Aluminum and methods of controls are discussed.

Key words: Aluminum, infant milk powder, pediatrics, Assiut university hospital.

\section{INTRODUCTION}

Infant milk powder formulae are the most important food for babies from $(0-6)$ months because it may be the only food at that age specially when replaced mother milk for any reason as unhealthy babies so it is important to sure that this formula must be free from any harmful agents specially trace elements as aluminum.

Aluminum considered one of the very important element which may present normally in food or may contaminate it from many sources during manufacturing, packing and distribution.

Infant milk powder contain negligible amount of aluminum ions come from raw milk itself while manufacturing machines, cooking pots, pans tools and utensils act as additional sources of aluminum (Uluozluet et al., 2009) or from drinking water at time of reconstitution (Adam., 2013).

Low level aluminum intake is not harmful but high concentration of metal can be extremely toxic (Yokel and Allen., 2004) which must be within the rang of legal limit 0 - 4 ppm (Egyptian organization for standardization and quality control 2012) 3000 - 4000 $\mathrm{mg} / \mathrm{kg}$ can be fatal specially in infant or when dietary calcium or phosphorus is low (NRC 2005).

Normal ingestion of it (3-5 mg/day $-15 \mathrm{mg}$ ) will absorbed through the wall of gastrointestinal tract and excreted through the kidney however if the intake is greater than $1000 \mathrm{mg}$ /day retention occure (Barreto and Araujo, 2011).

Aluminum accumulate in tissues such as brain, bone, liver, kidney, lung and milk (Lemire and Appanne 2011) and may cause organ dysfunction and serious health problem as renal damage, neurological disturbance (memory loss, tremor, jerking movement), permanent damage of the brain and end by Alzheimer's disease (Percy et al., 2011).

It may be accumulated in the brain and bone and may persistent more than any metabolic poisons and cause neurotoxin lesion (Garttner at al., 2009) causing damage of central nervous system, neurotoxicity, loss of memory restlessness and sever trembling (Flaten, 1990).

Due to the healthy importance of aluminum in human being from the time of birth till old ages this work is planned to estimate it in infant milk powder formulae serving in pediatrics Assiut university hospital.

\section{MATERIALS and METHODS}

\section{Collection of samples:}

A total of 30 random samples of infant milk powder serving in pediatrics Assiut university hospital were collected at the time form January to March 2014 in clean, dry and sterile containers from food department of pediatrics Assiut university hospital. Samples were dispatched to the laboratory with a minimum of delay where they were examined. 
Determination of Aluminum concentration in milk samples:

Preparation and digestion of samples:

Milk samples were digested according to Slavin et al. (1975) with some modification as the follow:

From each milk sample, $25 \mathrm{ml}$ was drawn with clean sterile $25 \mathrm{ml}$ glass pipette and placed in clean dried $250 \mathrm{ml}$ Erlenmeyer flask.

Erlenmeyer flasks that contained milk samples were put in hot air oven at $100 \mathrm{C}$ for half an hour and then were left at $50 \mathrm{C}$ for 24 hours till evaporation of water from the sample.

$25 \mathrm{ml}$ digestion mixter (Equal volumes of concentrated nitric acid and $72 \%$ perchloric acid) was added to each flask, shacked and the acid was allowed to react at room temperature for 24 hours to facilitate the processes of digestion.

After this the flasks were put on hot plate at approximately 100C, shacked and several milliliters of concentrated nitric acid were added each flask during the process of heating. Heating continued till the sample become colorless (complete digestion of the sample and disappearance of the brown gas (Nitric oxide, $\mathrm{NO}_{3}$ ) after its evaporation from the flask).

Samples were allowed to cool, filtered with filter paper, flasks then washed out several times with ion free water till the final volume of the digested sample reach $25 \mathrm{ml}$. These samples stored at refrigerator tell their analysis and estimation of Aluminum.

Determination of aluminum in milk samples: Aluminum in ppm was estimated in the digested milk samples by means of, atomic absorption spectrophotometer at the central laboratory in the faculty of veterinary medicin -Assiut university (Szkoda and Zmudzki, 2005) Shimadzu Atomic absorption / flam spectrophotometer ModelAA63002P / N204-27600-02AA630-02), Kyoto-Japan.

\section{RESULTS}

Table 1: Statistical analytical results of aluminum concentrations (ppm) in the examined infant milk powder samples:

\begin{tabular}{lccccc}
\hline Metal & $\begin{array}{c}\text { N. of exam. } \\
\text { samples }\end{array}$ & +ve samples & Min. & Max. & Average \\
\hline Aluminum & 30 & 30 & 0.0619 & 0.9601 & 0.4027 \\
\hline
\end{tabular}

Table 2: Frequancy distributhion of the examined infant milk powder samples based on thier aluminum concentration (ppm):

\begin{tabular}{lcc}
\hline & N. of samples $/ 30$ & \% of +ve samples \\
\hline $0.0-$ & 7 & 23.3 \\
\hline $0.2-$ & 9 & 30 \\
\hline $0.4-$ & 9 & 30 \\
\hline $0.6-$ & 3 & 10 \\
\hline $0.8-$ & 2 & 6.7 \\
\hline
\end{tabular}

\section{DISCUSSION}

Human milk is considered to be the best source of nutrition for the infants (Picciano, 2001). But infant milk powder is generally recommended in developed and developing countries when it is difficult to bring up an infant on mother's milk so we must sure that milk is of good keeping quality and free from any harmful agent as trace elements specially aluminum due to its harmful effect in neonatal age as it may accumulate in tissue such as brain, bone, liver, kidney and lung causing organ dysfunction and serious health problems as renal damage, neurological disturbance (memory loss, tremor, jerking movement), permanent damage of the brain and end by Alzheimer s disease (Percy et al., 2011).

AL contamination occurs during the manufacturing or storage processes in tin pack lining with $\mathrm{Al}$ foil, although this can be avoided using the adequate 
control packing procedures (Narin et al., 2004).

The results summarized results in Table 1 showed that $30(100 \%)$ samples contaminated with aluminum and its concentration (ppm) in the examined infant milk powder samples ranged from 0.0619 to 0.9601 with an average $0.4027 \mathrm{ppm}$

The results in table 2 showed that the highest frequency distribution was $18(60 \%)$ lied within the range of 0.2 and $0.4 \mathrm{ppm}$.

Higher results were obtained by Sibel et al. (2007) who indicted that the original raw milk contain high $\%$ of trace elements may be come from animals food or dairy environment and dairy utensils and equipment. On the other hand it may be contaminated during manufacturing by using metal machines or tin containers of foil lining packing or from contaminated drinking water which used to reconstitute infant milk powder at time of use.

Nearly similar results were obtained by Vinfas et al. (1997), Tasneem et al. (2004), Deeb and Gomaa, (2011), Salah et al. (2013).

According to Egyptian organization for standardization and quality control (2012) that lied within the range of legal limit $(0-4 \mathrm{ppm})$ which indicate that products come from dairy farm produce raw milk contain permissible limit of trace element specially aluminum and not contaminated during manufacturing by any sources of it.

\section{CONCLUSION}

Aluminum content in infant milk powder samples suggests that contamination occurs during the manufacturing or storage processes in containers although this can be avoided using the adequate control packing procedures.

So infant milk powder must be come from a manufacture source or dairy processing plant which not only characterized by HACCP system but also has a great attention towards contamination by trace elements.

Periodical examination of infant milk powder locally manufactured or imported one must take place to insure that agreeing with Egyptian organization for Standardization and Quality Control and excluded any kind of it not agree.

\section{REFERENCES}

Adam, W.K. (2013): Aluminum level in feed stuffs, drinking water and Brain Tissue of cattle in upper Egypt. Thesis M. Vet. Sci. Forensic Med. \& Toxi. Fac. Vet. Med. Assiut Univ.
Barreto, F. and Araujo, S. (2011): Aluminum Toxication in chronic kidney diseases. J. Bras Nefrol Apr- Jun; 33(2): 211-215.

Bohrer, D.; Cicero do Nascimento, P.; Binotto, R. and Pomblum, S.C. (2001): Influence of the glass packing on the contamination of pharmaceutical products by aluminum. Part I: Salts, glucose, heparin and albumin. J. Trace Elem. Med. Biol. 15, 95-101.

Deeb, A.M.M. and Gomaa, G.M. (2011): Detection of Aluminum in some dairy productes at KafrEl-sheikh, Egypt. Global Veterinaria 6(1): 0105. ISSN 1992-6197.

Egyptian organization for Standardization and Quality Control (2012): Maximum level of heavy metal contaminate in food Egyptian Organization ST. ES. 2360.

Flaten, T. (1990): Geo graphical association between aluminum in drinking water and death rates with dementia (including Alzheimer s disease), Parkinson s disease and amyotrophic lateral sclerosis in Norway Environmental Geochemistry and health, 12, 152-167.

Garttner, S.; Balski, M.; Koch, M. and Nehls, I. (2009): Analysis and migration of phosphates in infant food packed in recycle paper board. J. Agric. Food Chem. 57(22): 106.75-81.

Lemre, J. and Appanna, V. (2011): Aluminum toxicity and astrocyte dysfunction; A metabolic link to neurological disorders $\mathbf{J}$ Inorg. Biochem 105(11)1513-7. Epub Jul 23.

Narin, I.; Tuzen, M. and Soylak, M. (2004): Aluminium determination in environmental samples by graphite furnace atomic absorption spectrometry after solid phase extraction on amberlite XAD-1180/pyrocatechol violet chelating resin. Talan 63, 411-418.

NRC (National Research Council, 2005): Mineral Tolerance $s$ of Demostic Animals, Washington. DC: Nationall Academy of Sciences. Proc. Natl Aacard Sci, 877: 1043-1064.

Percy, M.; Kruck, T.; Pogue, A. and Lukiw, W. (2011): Towads the prevention of potential Aluminum toxic effect and an effective treatment of Alzheimer sdisease. J. Inorg. Biochem. 105(11): 1505-12.

Picciano, M.F. (2001): Nutrient composition of human milk. Pediatr. Clin. North Am. 48, 5367.

Salah, F.A.A.E.; Esmat, I.A. and Mohamed, A.B. (2013): Heavy metals residues and trace elements in milk powder marketed in Dakahlia Governorate International Food Research Journal 20(4): 1807-1812.

Sibel, S.; Kadriye O. Saygi; Ozgur D. Uluozlu; Mustafa T. and Mustafa, S. (2007): Determination of trace element contents of babyfoods from Turkey food Chemistry 105 (2007) 280-285. 
Slavin, S.; Barnett, W.B. and Kahn, H.L. (1975): The Determination of Atomic Absorpation Detection Limits by Direct Measument. Atomic Absorption Newsleter 11: 37-41.

Szkoda, J. and Zmudzki, J. (2005): Feasibility of microwafe digestion for determination of trace elements in Biological by atomic absorption spectroscopy methods. Bromat. Chem. TOKSYKOL., 28: 369-375.

Tasneem, G.K.; Nusrat, J.; Jameel, A.B.; Hassan, I.A.; Ghulam, K.; Mohammad, B.A.; Mohammad, K.J. and Abdul, Q.S. (2004): Determination of toxic elements in infant formulae by using electrothermal atomic absorption spectrometer food and chemical Toxicology 47(2009)1425-1429.
Uluozluet, O.; Tuzen, M.; Mendil, D. and Soylak, M. (2009): Assessment of trace element content of chicken prodcts from Trkey J. Hazard Mater., 163(2-3): 982-7.

Vi nfas, P.; Campillo, N.; LopezGarcia, I. and HernandezCordoba, M. (1997): Electrothermal atomic absorption spectrometric determination of molybdenum, aluminium, chromium and manganese in milk Analytica Chimica Acta $356267 \pm 276$.

Yokel, R. and Allen, D. (2004): Dissimilar and gallium permeation of the blood -brain barrier demonstrated by in vivo microdialsis. J. Neurochem., 58: 903-908.

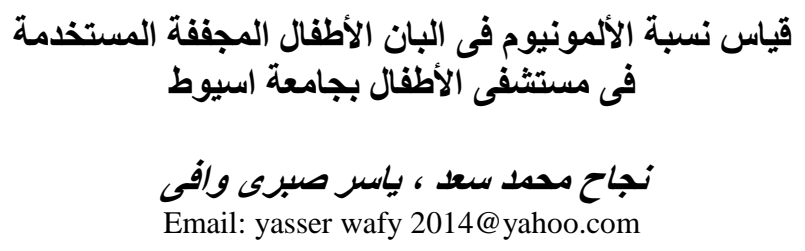

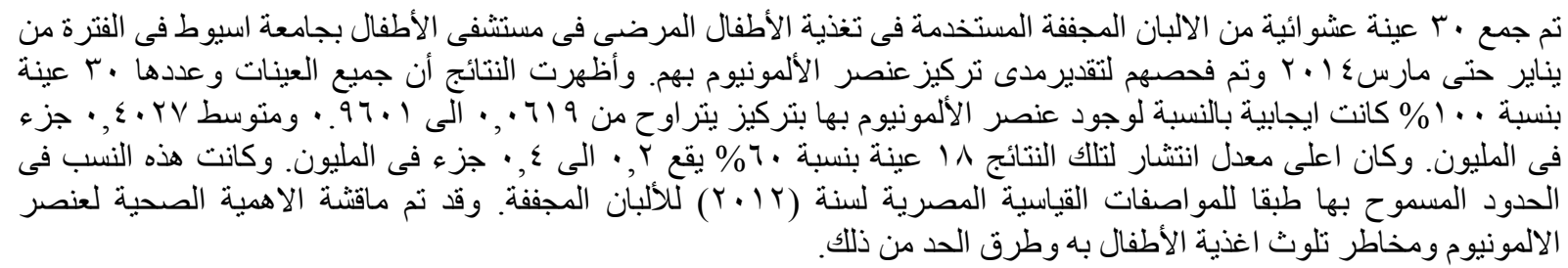

